\title{
$>$ De Paisagens Escritas e Paisagens Pintadas: vínculos conceituais entre a pintura de Hipólito Caron e o romance Inocência de Alfredo Taunay
}

\author{
> From Written Landscapes And Painted Landscapes: conceptual bonds \\ between Hipólito Caron's painting and Alfredo Taunay's novel Inocência
}

\section{por Ana Carla de Brito}

Bacharel em Artes Plásticas pela CEART - UDESC. Doutoranda em Artes Visuais pelo PPGAV, UFRGS, na área de concentração de História, Teoria e Crítica, sob orientação do Prof. Dr. Paulo Gomes. E-mail: acarla.brito@gmail.com. ORCID: 0000-0002-0754-3775.

\section{Resumo}

Neste artigo esboçaremos alguns vínculos conceituais entre palavra e imagem, que se evidenciam em uma obra literária de Alfredo Taunay e na produção pictórica de Hipólito Caron. Evidenciamos tais ligações recuperando um antigo paralelo entre a pintura e a literatura, cuja origem remonta à doutrina ut pictura poesis de Horácio no século I, que coloca a poesia em relação à pintura. Em seguida, demonstramos que o paralelo das artes está implicado na criação das Academias de Belas Artes e na valorização do desenho mediante a noção de desígnio no Renascimento. Por último, chegamos à discussão quanto à verossimilhança no romance e na pintura do século XIX, ligando-a diretamente às características do romance de Taunay e às pinturas de Caron. Palavras-chave: Pintura de Paisagem. Hipólito Caron. Narrativa. Alfredo Taunay. Paralelo das Artes.

\begin{abstract}
In this paper we present some conceptual bonds between word and image, which are evidenced in Alfredo Taunay's literary work and in pictorial production of Hipólito Caron. We show these bonds recovering an old parallel between painting and literature, whose origin reassembles Horacio's doctrine ut pictura poesis in the first century, which puts poetry in relation to painting. Then, we demonstrate the parallel of the arts is implicated in the creation of the Academies of Fine Arts and the valorization of drawing through notion of disegno in the Renaissance. Finally, we come to discussion about the verisimilitude in the novel and in the 19th century painting, which is directly related to characteristics of Taunay's novel and Caron's paintings.
\end{abstract}

Keywords: Landscape Painting. Hipólito Caron. Narrative. Alfredo Taunay Parallel of Arts. 


\section{Paisagens em palavras e tintas}

Entre a palavra e a imagem, que relações poderiam haver? A palavra poderia conferir visibilidade? A imagem poderia narrar? Poderia também esta ser apenas, e tão somente, imagem, sem evocar narrativas? Entre palavras e imagens que narram ou tornam o mundo visível, que razões poderiam haver para preferir um ou outro modelo? Neste artigo esboçaremos alguns vínculos conceituais entre palavra e imagem que se evidenciam em uma obra literária de Taunay e na produção pictórica de Hipólito Caron. Partimos das duas produções para recuperar um paralelo das artes bastante antigo, que relaciona a literatura e a pintura.

A obra Inocência foi escrita por Alfredo d'Escragnole Taunay (1843-1899) e publicada em 1872, durante o Segundo Reinado. O enredo da obra se desenrola em torno do envolvimento amoroso de Inocência, uma moça simples e interiorana, e Cirino, um jovem farmacêutico que é hospedado pelo pai dela. Embora Inocência seja mantida praticamente reclusa, a severa vigilância paterna é contornada pelas circunstâncias da enfermidade de que ela é acometida, de modo que o contato com o rapaz é oportunizado pelo tratamento que este se dispõe a ministrar. Toda a trama se passa no sertão mato-grossense, que é tornado visível tanto pela caracterização do entorno dessa casa em que se acolhem viajantes, quanto pelos deslocamentos realizados por alguns dos personagens.

Percebemos nas primeiras páginas da obra que as palavras ali são postas mais para suscitar imagens do que para evocar ações. Partindo de uma delimitação geográfica precisa, o autor nos aproxima da paisagem, delineando pouco a pouco uma estrada e seus arredores. De maneira rítmica e gradativa, a prosa instaura a sensação de que caminhamos junto do narrador, enquanto este nos indica o que olhar, conferindo formas e cores ao cenário esboçado. Mediante as palavras que se sucedem, as imagens se alternam entre panoramas - os olhos se estendem até o horizonte, vasculhando as árvores do cerrado, e aproximações - a prosa nos conduz a atentar para a areia da estrada, verificando a sua cor, textura e densidade. Situações que modificariam os aspectos apresentados, como 
a queimada e a chuva reparadora que poderia sucedê-la, são evocadas de forma vívida e detalhada, qualificando as interações dos animais com o ambiente a partir de metáforas que os aproximam de sentimentos humanos.

Cerca de dez anos depois da publicação de Inocência, um grupo de pintores deixa de tomar aulas na Academia Imperial de Belas Artes, acompanhando Georg Grimm, que fora desligado do ensino da disciplina de pintura de paisagens, flores e animais. Um desses estudantes, que se torna discípulo de Grimm, é Hipólito Caron. Tendo lecionado como professor interino entre 1882 e 1884, o artista alemão é citado em diversos textos ${ }^{1}$, como aquele em que teria introduzido a prática da pintura ao ar livre como método de aprendizado da pintura de paisagem. Ao sair da Academia, Grimm e os estudantes que o seguiram passaram a pintar em Niterói, esboçando suas composições paisagísticas da observação direta nas quais a verossimilhança compareceria como característica preponderante, o que pode ser visto na caracterização cuidadosa das rochas na pintura Rochedo da Boa Viagem (Figura 1), de Hipólito Caron.

Segundo o crítico de arte oitocentista, Gonzaga-Duque, a Grimm caberia o mérito de ter fundado a primeira escola brasileira de paisagistas, alçando esse gênero de pintura à representação das cores da nossa natureza. ${ }^{2}$ Pesquisas recentes, porém, têm elucidado que a preocupação em compor paisagens que expressassem a singularidade da natureza brasileira já existia entre os pintores acadêmicos na década de 1850. Ainda assim, é a partir de Grimm, e em sua época como professor, que o método da observação direta da natureza se conjuga a uma mudança de posicionamento com relação à tradição. Com Grimm e também, posteriormente, com Zeferino da Costa (1840 - 1915), a prática preliminar de cópia de estampas é eliminada das aulas de pintura de paisagem, o que poderia demonstrar, segundo Ana Maria Cavalcanti, que os artistas dessa época

\footnotetext{
${ }^{1}$ Dentre os textos de historiadores, é bastante citado o trecho de Arte Brasileira de Gonzaga-Duque (1995, p. 194) em que o autor relata a maneira irreverente com que Grimm teria conclamado seus estudantes a aprenderem com a observação da natureza, sem etapas preliminares.

${ }^{2}$ Gonzaga Duque, A Arte Brasileira, 1995, p. 193.
} 
conferiam uma importância maior ao desenvolvimento de uma maneira própria de pintar, do que ao domínio de uma representação correta de proporções ou perspectiva. $^{3}$

Na pintura de Caron (Figura 1), uma elevação rochosa se ergue junto ao mar, ocupando mais da metade do quadro. Boa parte de sua constituição parece ter sido desconsiderada pelo enquadramento. Uma vegetação arbustiva se espalha pela grande rocha até o seu cume, enquanto junto a sua base rochas menores se espraiam banhadas pelas ondas que ali arrefecem. O mar é percebido em uma estreita faixa horizontal na porção esquerda entre as rochas e os outeiros azulados pela distância. No restante da pintura, observa-se o céu com nuvens pouco espessas - a contraparte triangular do rochedo - estendendo-se pela porção esquerda e superior da composição.

O tratamento do rochedo é minucioso; vemos suas quinas afiadas, percebemos algumas reentrâncias, distinguimos fissuras e até mesmo vislumbramos a espessura da parede formada em torno da fenda que a rocha porta, cuja posição é quase central. A atenção concedida às rochas é também evidenciada pela composição. O grande volume rochoso se apresenta cindido: não nos é dado apreender a totalidade do outeiro. Posicionado à direita e ocupando mais da metade da tela, o monte confina com o mar. Nossos olhos podem se deslocar do topo do rochedo até os seixos no primeiro plano, contornando a silhueta da elevação através das leves camadas de azuis do céu e espraiando-se junto à rebentação. Do primeiro plano o olho perscruta, então, a fenda próxima a uma face parcialmente iluminada no rochedo, mais à direita. Temos, pois, um movimento semi-helicoidal, como se acompanhássemos com os olhos o início de uma espiral.

\footnotetext{
${ }^{3}$ Ana Maria Tavares Cavalcanti, Da prática das cópias às imagens de referência na pintura de Eliseu Visconti, 2002, p. 34.
} 


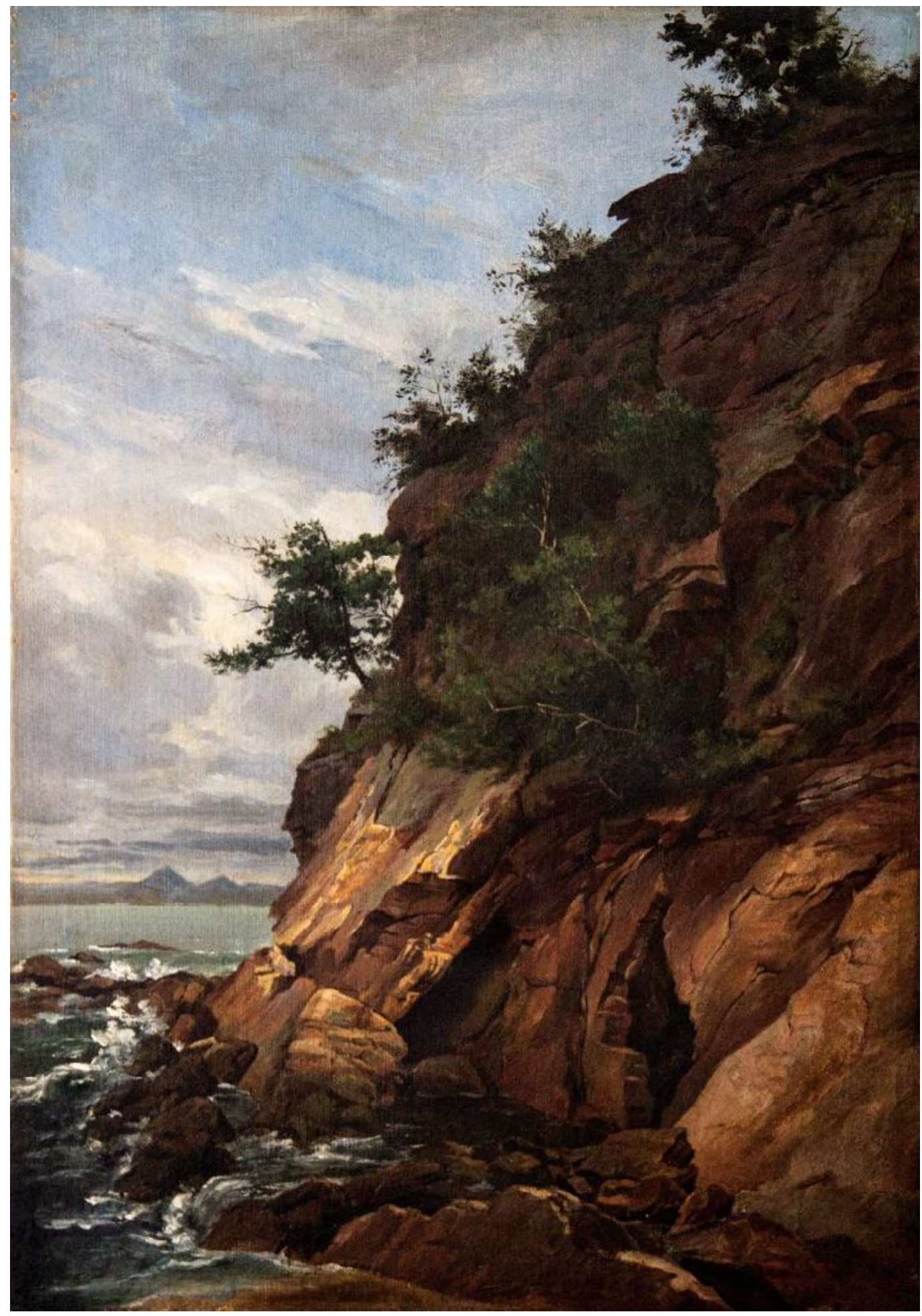

Figura 1

Hipólito Caron, Rochedo da Boa Viagem, 1884, óleo sobre tela. Coleção Particular, Rio de Janeiro, RJ. 
Esse modo de composição, que abarca uma porção exígua da paisagem, representando-a com minúcia, reverbera uma estética da pintura que é posterior à paisagem romântica e que pode ser identificada com a pintura dos paisagistas de Barbizon:

[O] foco em recortes mais limitados da paisagem, que permitissem uma experiência de contato e visualização mais próxima e intensa do objeto, ia assumindo mais e mais a preferência dos paisagistas de vanguarda, como trechos do interior de florestas, fechados e sem evidenciar a recessão do espaço e do horizonte, concentrando-se a atenção em formas e cores, e como se apresentavam à vista sob certa luz. ${ }^{4}$

A verossimilhança da imagem que representa a natureza brasileira é preconizada tanto no romance de Taunay quanto nas pinturas de paisagem de Caron, nos primeiros anos de sua carreira (1882 - 1884). Essa fidedignidade relaciona-se com a noção de cor local, que, por sua vez, liga-se ao programa do nacionalismo estético vigente na literatura brasileira desde a geração romântica da década de 1830, sendo cara também aos românticos tardios, como Alfredo Taunay, e também na pintura da segunda metade do século XIX.

O conceito de cor local está, portanto, associado à busca por especificidades do lugar. Nesse sentido, pode ser associado também ao pitoresco, pois, dentre os sentidos que Argan atribui a essa noção, está a busca do particular e característico em oposição ao belo universal. ${ }^{5}$

\section{Elos distantes}

Há mais vínculos, porém, do que poderíamos supor apenas atentando para o caráter pitoresco das obras. A alusão a imagens por meio de palavras estava prevista na composição de poesias na antiguidade clássica, de modo que o paralelo entre pintura e literatura remonta a esse período; entretanto, seu impacto e historicidade é sentido até o século XIX. Tendo contribuído para

\footnotetext{
${ }^{4}$ Valéria Salgueiro, Antônio Parreiras: notas e críticas, discursos e contos - coletânea de textos de um pintor paisagista, 2000, p. 31.

${ }^{5}$ Giulio Argan, Arte Moderna, 2008, p. 18.
} 
engendrar uma maneira de conceber imagens constitutivas da pintura renascentista, o recorrente resgate da cultura clássica nos séculos seguintes consolida esse amálgama há muito forjado.

Inicia-se, pois, como debate teórico, por meio da expressão elaborada por Horácio em sua epístola aos pisões datada do primeiro século da Era Cristã: ut pictura poesis; a expressão significa o poema é como um quadro. Conforme Lichtenstein, os escritos de Horácio recuperavam a assertiva de Simonides de Ceos (556 - 468 a.C.), para o qual o sentido da visão era superior ao da audição, de modo que tal sentença se configurava em um privilégio da pintura, em cujos atributos visuais a poesia procuraria se espelhar. ${ }^{6}$ Entretanto, os teóricos do renascimento acabaram por interpretar essa sentença de uma maneira que invertia a hierarquia. Embora continuassem utilizando a frase ut pictura poesis, a interpretação renascentista passava a se esboçar como uma ut poesis pictura - ou seja: a pintura deveria ser como uma poesia.

Segundo a nova compreensão, a pintura seria uma poesia muda e a poesia um quadro em palavras. Assim, ao mesmo tempo em que dava à pintura o epíteto de poesia muda, revestindo-a com as características racionais da palavra e do pensamento, essa fórmula acabava por lhe conferir um lugar secundário em relação à poesia, uma vez que esta era qualificada com duas características positivas, pintura falante, ao passo de que a insígnia que a pintura portava parecia indicar uma insuficiência: a de uma poesia que careceria de fala. A ponte entre as duas artes estaria, pois, constituída por uma descrição que traduziria em palavras o silêncio da pintura.

O espelhamento invertido se devia ao fato de as belas letras gozarem de um status superior ao das belas-artes. Preconizando a herança clássica, os artistas italianos do renascimento compartilhavam com os antigos o apreço pela razão, atribuindo à ideia um alto valor. Em contraponto a essas noções, de modo semelhante aos antigos, as atividades que não guardassem estreita ligação com o

\footnotetext{
${ }^{6}$ Jacqueline Lichtenstein, A pintura: textos essenciais, v. 7: O paralelo das artes, 2005, p. 9-11.
} 
exercício do pensamento, ou seja, aquelas que consistissem em um fazer meramente manual, em que a razão não operasse, eram consideradas menos dignas.

A maneira encontrada de elevar a pintura de uma atividade servil em que apenas operam os sentidos que apreendem o visível, transfigurando-o mimeticamente através do labor manual foi, então, dupla. Primeiramente, a pintura foi ancorada no desenho. Este é compreendido como desígnio: o desenho seria um projeto, coisa mental por meio de que a razão ordena o mundo. Em segundo lugar, a fabricação de imagens não se reportaria a um despropósito descritivo, no sentido de apenas emular a natureza, copiando-a servilmente. Antes, encenaria uma narrativa, figuraria uma istoria, ao modo de uma poesia muda. Nesse ínterim, comparecem como estratégias a perspectiva, que permite racionalizar e ordenar o espaço, compondo-o como ambiente cenográfico para os fatos inauditos figurados, e a retórica, a partir da qual as imagens são interpretadas. Essa última reporta-se à prática da écfrase, provinda também da antiguidade clássica.

Tendo sua origem inscrita no contexto da Segunda Sofística, tal prática encontrou em Filóstrato, o velho, seu maior expoente. Como descrição oral de obras de arte, a écfrase não ambicionava tornar visíveis imagens que não estivessem presentes materialmente ante seus apreciadores. Antes, intentava evidenciar o sentido das imagens que eram contempladas, de modo que a descrição elogiosa era comumente feita enquanto os olhos percorriam o objeto da descrição.

De fato, no início do pequeno livro Amores e outras imagens, quando as explicações de Filóstrato são solicitadas pelo filho de seu anfitrião, o sofista e seu auditório se encontram frente a pinturas da galeria anexa à casa em que estava hospedado. Além disso, antes de narrar o ocorrido, Filóstrato diz que seus discursos explicam a natureza das pinturas, "compondo lições aos jovens para 
que as interpretem e apreciem o que há de excelente nelas"7. A descrição retórica se manifesta, então, como uma ferramenta hermenêutica. Seria, portanto, através da écfrase que a pintura - essa poesia muda - ganharia voz. Dentro do sistema logocêntrico herdado da tradição clássica, a filiação da pintura a uma composição narrativa seria imprescindível, posto que, com vistas a estabelecerse como arte liberal, a pintura emprestaria da narratividade o prestígio das letras.

\section{Narrar com o pincel}

A filiação da pintura a um sistema narrativo deu-se efetivamente com o surgimento das Academias de Belas Artes. A formação do sistema de ensino artístico acadêmico na França apresentou um ingrediente político que reforçou a referência das letras para a pintura. ${ }^{8}$ A criação da Academia francesa ocorreu com o amparo do governo, justificando, em parte, a sua existência no serviço que prestava aos dirigentes políticos. Segundo relata Celina Moreira de Mello, a fundação da Real Academia de Pintura e Escultura na França, em 1648, pelo rei Luís XIV correspondeu a uma estratégia política. ${ }^{9}$ Ante o descontentamento de parte da nobreza em relação à centralidade do governo real, que motivou diversos conflitos no episódio conhecido como Fronda, os ministros do rei (que então contava apenas dez anos de idade) consideraram importante atender à solicitação de um grupo de artistas pela formação de uma instituição artística que promovesse a imagem do monarca, uma vez que as corporações de ofício, imperantes na produção de imagens desde 1391, alinhavam-se aos nobres insurgentes.

A distinção em relação às corporações de ofício, bem como a edificação de um sistema artístico intelectualizado que elevasse a pintura da condição de

\footnotetext{
${ }^{7}$ Filóstrato, Amores e outras imagens, 2012, p. 18.

${ }^{8}$ Detemo-nos na instituição francesa, a princípio, devido à questão política implicada, e porque ela seria o modelo que a Academia Imperial de Belas Artes brasileira seguiria, tendo em vista que foi criada com a contribuição de artistas franceses que chegaram no país em 1816.

${ }^{9}$ Celina Mello, A literatura francesa e a pintura - ensaios críticos, 2004, p. 21 a 42.
} 
artes mecânicas à de artes liberais era o anseio desse grupo de artistas que se aproveitou das circunstâncias políticas para concretizar seus planos; esse desejo de distinção está ligado à origem das academias de arte. Os italianos inauguraram o ensino acadêmico de Arte com a fundação da Academia de Desenho de Florença por Giorgio Vasari, em 1562, impelidos pelo mesmo motivo: edificar uma pintura intelectualizada, cujo ensino se diferenciasse daquele oferecido pelas guildas, por meio de uma formação que demonstrasse um olhar erudito e liberdade de espírito, em contraponto às técnicas puramente manuais.

Do compromisso em esboçar representações dos feitos políticos já se depreende parte dos motivos de a pintura de história ser tida em maior valor do que a paisagem. No entanto, além dessa, há uma questão filosófica que se reporta ao estatuto de maior racionalidade conferido às modalidades de pintura que estariam mais firmemente ancoradas no desenho. Retornando ao exemplo da academia francesa, a conferência de Charles Le Brun em 1672 é contundente a esse respeito.

Respondendo ao discurso de outro conferencista que havia feito a defesa dos pintores coloristas, o diretor da Academia Real de Pintura e Escultura reafirma o estatuto basilar do desenho, uma vez que a tripla finalidade a que a instituição se propunha - pedagógica, teórica e política - fundamentava-se nele. É através do desenho que seria possível ensinar pintura, pois era tido como a única parte dela que se submetia a regras. Além disso, essa prioridade sustentaria ainda a hierarquia dos gêneros pictóricos, em que a pintura de história era o mais valorizado: apenas uma pintura calcada no desenho poderia "transformar o relato em imagem, a história em quadro, ou, para usar os termos da época, narrar com um pincel"10. Dessa forma, enquanto na renascença italiana a centralidade do desenho era apenas uma corrente ou tendência de interpretação da obra de arte, na França do século XVII tornou-se uma teoria dominante.

\footnotetext{
${ }^{10}$ Jacqueline Lichtenstein, A pintura: textos essenciais, v. 9: O desenho e a cor. 2006, p. 14.
} 
Apoiada nesta, assim como em outras doutrinas, a academia procurou diferenciar-se do grupo dos Mestres "por seus conhecimentos, por seu domínio técnico, e, sobretudo, pela inscrição em uma Antiguidade Clássica, e não mais medieval"11. Os artistas solicitantes aludiam a uma liberdade e erudição da idade clássica, que teria soçobrado com o advento das corporações e seu modo de produzir imagens que se afasta das letras. Para tal concepção, retomar os parâmetros clássicos significaria uma reparação histórica.

Na hierarquia dos gêneros pictóricos, portanto, a pintura de história era aquela que estava mais próxima de uma maneira de pintar racional, ancorada no desenho e na possibilidade de narrar, aproximando-se, desse modo, também do status elevado das letras, às quais jamais havia sido negado o epíteto de artes liberais ou do espírito. Já a pintura de paisagem, era frequentemente associada a características depreciativas, sendo tida como mais intuitiva, avessa ao desenho e mais próxima da mancha colorista - a modalidade de pintura que não narra, apenas descreve o entorno; faltaria a ela um propósito.

Ressoa junto a essa reflexão em que confluem os conceitos de narrativa e desenho-desígnio a assertiva de Charles Le Brun, em seu discurso já mencionado à academia francesa. Segundo ele, a pintura de história seria o gênero pictórico em que os atributos racionais da pintura estariam plenamente reunidos; ou seja, feitos célebres poderiam ser narrados com um pincel. $\mathrm{Na}$ pintura brasileira da segunda metade do século XIX, porém, a fórmula de Horácio poderia ser retomada como havia sido concebida originalmente.

\section{Paisagem para uma escola nacional}

Outras variantes, porém, contribuem para ampliar a discussão sobre o lugar da pintura de paisagem no Brasil do século XIX. Arthur Valle e Camila Dazzi sinalizam que desde muito cedo, na formação da Academia no Brasil, a

${ }^{11}$ Celina Mello, A literatura francesa e a pintura - ensaios críticos, 2004, p. 24. 
pintura de paisagem foi vista como gênero cuja prática seria bastante proveitosa em nosso país, devido à exuberância de sua natureza. ${ }^{12}$ Aludindo aos primeiros estatutos da Academia Imperial de Belas Artes, redigidos em 1820, os autores afirmam essa atenção consciente em relação à possibilidade de associação entre o gênero e a constituição de uma escola nacional. Eis o trecho dos estatutos:

Este gênero de pintura é um dos mais agradáveis da Arte e o vastíssimo terreno do Brasil oferece vantagens aos Artistas que viajarem pelas Províncias, fizerem uma coleção de Vistas locais terrestres como marítimas: o Professor desta Classe ensinará a teoria e a prática, explicando os preceitos da perspectiva aérea, e o efeito da luz nas diversas horas do dia conforme a altura do Sol; por serem muito distintos os quatro tempos do dia; além do estudo dos reinos Animal e Vegetal muito necessários ao Pintor de Paisagem, exemplificará aos Discípulos a maneira de pintar as nuvens, árvores, águas, edifícios, embarcações, e todos os mais objetos que entram na composição de uma Vista terrestre, ou Marinha.

Após a declaração da independência, a busca pela constituição de uma escola nacional tornou-se premente para a intelectualidade do país. Manuel de Araújo Porto Alegre (1806 - 1879) encarna essas preocupações de maneira exemplar; Discípulo dileto de Debret, viaja com o professor para a Europa em 1831, fundando a Revista Niterói em 1836, junto de Gonçalves de Magalhães e Francisco de Salles Torres Homem, quando ainda estava em Paris. Esse episódio é considerado o marco inicial do romantismo literário brasileiro e pode ser visto como paradigmático do profundo compromisso que ele teria com a configuração de uma arte autenticamente brasileira.

Ao comentar a exposição geral de 1843 no periódico Minerva Brasiliense (outro veículo de comunicação de que esteve à frente), Porto Alegre dava grande destaque à pintura de José dos Reis Carvalho, pintor de frutos e flores, detectando como característicos da pintura brasileira temas e motivos relativos à natureza. Anos depois, em 1855, então diretor da AIBA, ele propõe mudanças no ensino de pintura de paisagem, estabelecendo, assim, nos novos estatutos: "O professor de paisagem ensinará o desenho de sua cadeira, e ficará obrigado a ir com os seus

${ }^{12}$ Camila Dazzi; Arthur Valle. 'As bellezas naturaes do nosso paiz': o lugar da paisagem na arte brasileira, do Império à República, 2009. 
alunos mais adiantados estudar a natureza, e fazer-lhes à vista dela as explicações que forem convenientes ${ }^{\prime \prime}$.

Letícia Squeff registra a indisposição entre o diretor e o então professor de pintura de paisagem, August Müller, causada devido à insistência de Porto Alegre em relação às lições ao ar livre. ${ }^{14}$ Ela explicita também o aspecto controverso que, embora o diretor acreditasse que somente o contato direto dos estudantes com a natureza possibilitaria a esses o desenvolvimento de um "olhar brasileiro", o gênero da pintura de paisagem permanecia em um papel subalterno: "É o que explica, por exemplo, que os novos estatutos concedessem apenas quatro anos de pensionato na Europa para os alunos de paisagem e de gravura, enquanto os pintores de história, arquitetos e escultores podiam prolongar sua estada por seis anos" ${ }^{\prime \prime 5}$. Além disso, segundo a estudiosa observa, Porto Alegre demonstrava não estar ciente da autonomia que a pintura de paisagem vinha adquirindo na Europa desde o início do século, pois vaticinava a pintura à aquarela e o conhecimento de botânica como modelo a ser seguido pelos pintores de paisagem brasileiros, enxergando nas expedições científicas o ofício em que os paisagistas formados pela AIBA poderiam atuar. Parecia ignorar, conforme argumenta Squeff, a maneira como a paisagem vinha sendo praticada por Corot e Millet, "que desde meados da década de 1830 introduziram na pintura novas propostas temáticas, incorporando o homem comum e a natureza viva à representação

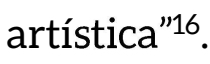

A ênfase na paisagem sugere a sintonia de Porto Alegre com as formas de sensibilidade que caracterizaram o romantismo literário brasileiro de que era participante e entusiasta. Entretanto, ainda que no círculo literário do qual fazia parte se tecessem poemas em que os fenômenos naturais eram evocados, junto à AIBA permanecia o primado da pintura de história, que ele próprio lecionara.

\footnotetext{
${ }^{13}$ Letícia Squeff, O Brasil nas letras de um pintor: Manuel de Araújo Porto Alegre (1806 - 1879), 2004, p. 212.

${ }^{14}$ Ibidem, p. 213.

${ }^{15}$ Ibidem.

${ }^{16}$ Ibidem.
} 
Esse era o gênero de pintura considerado completo, pois poderia reunir em um só quadro retratos de personagens ilustres, figuras humanas em sua vivacidade e movimento, além de aspectos da paisagem como ambiente cenográfico do acontecimento retratado. Ademais, a pintura de história se fiava no compromisso com a posteridade: "a intenção de fixar na memória um fato ou personagem significativo para a nacionalidade e a pátria"17.

Segundo essa noção de engrandecimento do país, desde que o Brasil foi reconhecido como nação independente até o início do período republicano, a pintura de história também seria convocada a erigir representações que conformassem a escola nacional. É a partir dessa significação que se estabeleceu, na Exposição Geral de 1879, uma sala dedicada à coleção de quadros nacionais formando a Escola Brasileira.

Conforme Tadeu Chiarelli, foi nesse momento que a direção da AIBA se posicionou publicamente sobre a questão, reunindo as obras que, segundo seu entendimento, representavam a escola brasileira: produções artísticas realizadas por mestres ou ex-alunos da Academia, em grande parte versando sobre temas nacionais - "Uma produção idealizada, voltada para a tradição acadêmica, mesclada por valores atenuados do romantismo e do realismo", afirma o autor. ${ }^{18}$

Dazzi e Valle sinalizam a rejeição da crítica da imprensa a essa exposição:

Escritores como Félix Ferreira, Gonzaga Duque, Oscar Guanabarino e França Jr. opuseram à proposta da Academia uma alternativa que valorizava a produção dos paisagistas brasileiros, em registro realista ou naturalista. Defendia-se a ideia de que a pintura de paisagem devia capturar o "característico" da pintura brasileira, sobretudo no que dizia respeito à sua luminosidade e às suas cores típicas. Essa ideia se distanciava decisivamente do partido usual até então, que subordinava a paisagem à história, e no qual o primeiro gênero se constituía essencialmente como pintura de atelier, como pode ser identificado em obras de pintores ilustres como Victor Meirelles e José Maria Medeiros. ${ }^{19}$

\footnotetext{
${ }^{17}$ Ibidem, p. 216.

${ }^{18}$ Tadeu Chiarelli, Gonzaga-Duque: a moldura e o quadro da arte brasileira, 1995, p. 19.

${ }^{19}$ Camila Dazzi \& Arthur Valle, 'As bellezas naturaes do nosso paiz': o lugar da paisagem na arte brasileira, do Império à República, 2009, p. 124.
} 
Rejeitando os feitos célebres em proveito do aspecto característico da paisagem, os críticos brasileiros não apenas se alinhavam à tendência europeia de valorização desse gênero de pintura, como declaravam que essa modalidade (junto à pintura de gênero) seriam as únicas alternativas capazes de fazer surgir no país uma arte nacional, com características próprias, ou seja, distintas daquelas dos outros países.

\section{Dos fatos inauditos aos preenchimentos}

Se colocarmos lado a lado o que era valorizado pela tradição e o que passa a ser reivindicado no século XIX por parte da intelectualidade brasileira, como exposto por Chiarelli e também por Dazzi e Valle, poderemos apreender que, dentre as oposições que regiam o paralelo das artes, o que era rejeitado passa então a ser elevado. ${ }^{20}$

O domínio do sensível é reabilitado: preconiza-se não a correção da natureza em prol do ideal e racional, mas sua figuração na maneira como é vista. A paisagem é pintada de maneira fidedigna, descrevendo o território brasileiro com suas cores e luz próprias, e, nesse momento, tal maneira não é vista como um servilismo que desabonasse a pintura, reduzindo-a a uma arte mecânica.

Além disso, também no Oitocentos a imagem se torna o referencial para o lógos. No Brasil, assim como na Europa, as palavras passam a ser empregadas cada vez mais em busca de conformar imagens. John Ruskin assinala esse duplo fenômeno: a proliferação de descrições nas letras no momento de consagração da pintura de paisagem. Na poesia inglesa diversos são os nomes dos poetas que exprimem versos descrevendo territórios e se deslumbrando com os movimentos da natureza, dentre os quais se destacam William Wordsworth (1770 - 1850) e Walter Scott (1771 - 1832). Este, na introdução do primeiro Canto de Marmion,

${ }^{20}$ Tadeu Chiarelli, Gonzaga-Duque: a moldura e o quadro da arte brasileira, 1995. 
pinta uma cena de fim de outono em que já se vislumbra o inverno. Ele descreve os efeitos do rigor do tempo na paisagem:

O céu de novembro é frio e deprimente, e as folhas das árvores, vermelhas e secas. Outrora, olhando do alto de um desfiladeiro para baixo, para o escuro e estreito vale, você dificilmente reconheceria o regato sob o bosque verde, tão emaranhado ele havia crescido, já agora, murmurando rouco, ele é frequentemente visto por entre arbustos e espinhos [...].

É no gênero romanesco, porém, que as descrições do entorno se acomodam mais apropriadamente. Em 1856, quando Gonçalves de Magalhães publica o poema épico A confederação dos tamoios, José de Alencar escreve diversas cartas com críticas desfavoráveis, reprovando a forma literária que Magalhães escolheu para erigir o acontecimento como símbolo nacional de resistência ao colonizador lusitano. Segundo o autor de Iracema, a prosa romanesca teria sido mais adequada: "a forma com que Homero cantou os gregos não serve para cantar os índios"21, afirma em sua segunda carta sobre o tema. Outras observações desfavoráveis do romancista se reportaram à fraca musicalidade e unidade narrativa do poema, além da falta de arte na descrição da natureza brasileira e dos costumes indígenas.

As cartas trocadas pelos jornais são publicadas no mesmo ano em que aconteceu a disputa e, no ano seguinte, em 1857, José de Alencar publica $O$ Guarani, romance através do qual o escritor procuraria atestar as teses defendidas nas cartas mobilizadoras da polêmica. Busca, assim, em seu romance, demonstrar que a obra de Gonçalves de Magalhães estaria ainda muito atrelada às formas clássicas, apesar de historicamente ter sido ele o principal propagador das ideias românticas no Brasil.

Na literatura brasileira, o olhar que atenta para a paisagem tem acento programático, reportando-se ao fenômeno do nacionalismo estético. Impelidos a constituir uma obra literária autenticamente brasileira, cada geração de escritores reivindicaria para suas obras o epíteto de fundadora. A atenção para o

\footnotetext{
${ }^{21}$ José de Alencar, Cartas sobre a Confederação dos Tamoyos, 1856, p. 25.
} 
local, com a consequente descrição de lugares, cenas, fatos e costumes do Brasil colocaria obras diversas como O Guarani de Alencar e Inocência de Alfredo Taunay sob o mesmo emblema. E o romance, concorda Candido, consistiria na forma literária privilegiada para representar o característico e o particular.

Ainda que os primeiros romances de Alencar, como Iracema e O Guarani tragam um enredo e um lirismo que evocam a epopeia, nos seguintes, o escritor confere cada vez mais à sua prosa elementos que aproximam o enredo de seus leitores. Candido atribui, porém, a Franklin Távora e Alfredo Taunay o aprofundamento de determinados aspectos do romantismo, que teriam contribuído para "dar refinamento à análise, sentido ao regionalismo, fidelidade à descrição e naturalidade à expressão"22.

Esses dois últimos escritores repreendiam Alencar, acusando-o de falta de verossimilhança por acreditarem que as descrições alencarianas teriam sido compostas em gabinete, sendo mais tributárias ao que o escritor cearense lera do que daquilo que vira e vivenciara. De fato, como apontado por Candido, em obras como Inocência a verossimilhança conferida pela descrição é intensificada pelo entrecho em que as personagens são contemporâneas aos leitores e caracterizadas de um modo reconhecível em contextos não inacessíveis aos potenciais leitores.

A busca por verossimilhança se alinha ao programa do nacionalismo estético, como já mencionamos. De modo que as descrições não apenas delimitam o espaço da narrativa, como assinala a singularidade daquela porção do país. Há, porém, ainda outra função possível desempenhada pelas descrições da paisagem na obra de Taunay, que corresponde ao que o crítico Franco Moretti chamaria de preenchimento.

Ao caracterizar o romance do século XIX como próprio do século sério burguês, marcado pela regulação do cotidiano, Moretti contrapõe momentos de

${ }^{22}$ Antonio Candido, Formação da literatura brasileira: movimentos decisivos 1750-1880, 2013, p. 612. 
bifurcações (das ações dramáticas, em que uma decisão é tomada) aos de preenchimentos, que consiste na narração de momentos banais de caracterização da rotina das personagens, e mesmo descrições, em que a narrativa se suspende, ou nada de importante acontece. "Trata-se de um modo novo, secularizado, de contar uma história: o seu sentido está disperso em cem momentos diferentes; sempre precário, sempre insatisfatório e misturado à indiferença do mundo"23.

Em Inocência, de Alfredo d'Escragnolle Taunay, as descrições da natureza não apenas ambientam o enredo como fazem parte dele. Marcam o ritmo dos ambientes rurais, em tudo diverso da cidade. Demonstram, mesmo, a particularidade daquele modo de vida: alongam os olhos da imaginação na distância das longas estradas, conduzindo o leitor a existências singulares, enformadas pelo isolamento e o convívio com o canto das aves e o espreitar dos animais selvagens, na lida diária com as reses e os cavalos.

Fica evidente no primeiro capítulo que no romance importa menos o amor de Cirino e Inocência do que o pitoresco da vida sertaneja e o vislumbre do cerrado sul-matogrossense:

Se parece sempre igual o aspecto do caminho, em compensação mui variadas se mostram as paisagens em torno.

Ora e a perspectiva dos cerrados, não desses cerrados de arbustos raquíticos, enfezados e retorcidos de São Paulo e Minas Gerais, mas de garbosas e elevadas árvores que, se bem não tomem, todas, o corpo de que são capazes à beira das águas correntes ou regadas pela linfa dos córregos, contudo ensombram com folhuda rama o terreno que lhes fica em derredor e mostram na casca lisa a força da seiva que as alimenta; ora são campos a perder de vista, cobertos de macega alta e alourada, ou de viridente e mimosa grama, toda salpicada de silvestres flores; ora sucessões de luxuriantes capões, tão regulares e simétricos em sua disposição que surpreendem e embelezam os olhos; ora, enfim, charnecas meio apauladas, meio secas, onde nasce o altivo buriti e o gravata entrança o seu tapume espinhoso.

Esse trecho compõe o longo capítulo descritivo que Antonio Candido considerou uma ouverture, à maneira das óperas, devido à musicalidade e lirismo

${ }^{23}$ Franco Moretti, A cultura do Romance, 2009, p. 836. 
com que é composta. ${ }^{24}$ Além dessa passagem, em diversos outros momentos a caracterização da natureza sobressai, suspendendo a ação, mas possibilitando que uma bifurcação pudesse ser entrevista.

Uma noite, em que havia luar embaciado por ligeira bruma, tomou a sua aflição tal violência que ele decidiu fugir daquele local de sofrimentos e incertezas, logo na manhã seguinte.

Assente uma vez nesta resolução, ergueu-se do leito em que jazia prostrado pelo mais cruel desalento e, com algum custo, saiu para o terreiro, abrindo cautelosamente a porta da casa, a fim de não acordar os companheiros de quarto. Uma vez fora, sentou-se num tronco de madeiro e ali ao ar fresco e acariciador da madrugada, entrou com mais tranquilidade a pensar no caso.

Seria uma hora depois de meia-noite.

Estavam os espaços como que iluminados por essa luz serena e fixa que irradia de um globo despolido; luz fosca, branda, sem intermitências no brilho, sem cintilações, e difundida igualmente por toda a atmosfera.

Haviam já os galos cantado uma vez, e, ao longe, muito ao longe, de vez em quando, se ouvia o clamor das anhumapocas.

Levantou-se de repente Cirino.

Depois de alguma vacilação, deu uma volta por toda a habitação, pulando os cercados, e tomou o ramo do frondoso laranjal, a cuja espessa sombra se abrigou por algum tempo.

Achegou-se, em seguida, à cerca dos fundos da casa e parou no meio do pátio, olhando com assombro para uma janela aberta.

Um vulto ali estava!... Era o dela; Inocência.. Não havia duvidar.

A longa descrição do desassossego de Cirino, no capítulo $O$ idílio, é entremeada pela caracterização da atmosfera noturna. Como se pressente pela narrativa, aquele quadro introduziria uma ação que bifurcaria a narrativa, trazendo à baila tomadas de decisões que precipitariam determinados acontecimentos, contrariando a ordem das coisas como até então se apresentavam.

Em outro momento, o rapaz está se deslocando até a casa do padrinho de Inocência, Antônio Cesário, que reside próximo a uma povoação limítrofe com

${ }^{24}$ Antonio Candido, Formação da literatura brasileira: movimentos decisivos 1750-1880, 2013, p. 623. 
Minas Gerais, chamada Vila de Santana. Entre a vila e a sede rural em que seria abrigado a natureza varia de abjeta e potencial fonte de doenças, passando pela confluência com o estado de espírito do protagonista, para, enfim, evadir-se dele, apresentando-se solar e alegre, enquanto o rapaz permanecia desesperançado:

Cirino em pouco mais de uma hora, transpôs a distância da povoação ao rio. Também, na légua e quarto que até lá media só há de ruim o trecho em que fica a floresta que borda as margens da majestosa corrente.

Nessa mata, trazem os troncos das árvores vestígio das grandes enchentes; o terreno é lodacento e enatado; centro de putrefação vegetal donde irradiam os miasmas que, por ocasião da retirada das águas, se formam em dias de calor abrasador e sufocante.

Abundam ali coqueiros de estípite curto e folhuda coroa chamados aucuris, a que rodeiam numerosas lagoinhas de água empoçada e coberta de limo.

Em nada é, pois, aprazível o aspecto, e a lembrança de que ali imperam as temidas sezões faz que todo o viajante apresse a travessia de tão tristonhas paragens.

Ouve-se a curta distância o ruído do rio que corre largo, claro e com rapidez.

Como duas verdes orlas refletem-se no espelhado da superfície as elevadas margens, a cujo sopé moitas de sarandis, curvadas pelo esforço das águas e num balancear continuo, produzem doce marulho.

Causa-nos involuntário cismar a contemplação de grande massa liquida a rolar, a rolar mansamente, tangida por força oculta. Bem como a ondulação incessante e monótona do oceano agita a alma, assim também aquele perpassar perene, quase silencioso, de uma corrente caudal, insensivelmente nos leva a meditar.

E quando o homem medita, torna-se triste.

Franca e espontânea é a alegria, como todo o fato repentino da natureza. A tristeza é uma vaga aspiração metafísica uma elação inquieta e quase dolorosa acima da contingência material.

Ninguém se prepara para ficar alegre. A melancolia, pelo contrário, aos poucos é que chega como efeito de fenômenos psicológicos a encadear-se uns nos outros.

De que modo nasceu aquela enorme mole de água? Donde velo? Para onde vai? Que mistérios encerra em seu seio?

Largo tempo ficou Cirino a olhar para o rio. Em sua mente tumultuavam negros pensamentos. 
Já se havia difundido o crepúsculo, e bandos folgazões de quero-queros saudavam os últimos raios do sol e despertavam os ecos em descomunal gritaria. De vez em quando, passava algum pato selvagem, batendo pesadamente as asas; sobre as águas, adejavam garças estirando e encolhendo o níveo colo e pombas, aos centos, cruzavam de margem a margem a buscar inquietas o pouso de querência.

$[\ldots]$

A majestosa impassibilidade da natureza exasperava-o. Quando o homem sofre deveras, deseja nos raptos do alucinado orgulho, ver tudo derrocado pela fúria dos temporais, em harmonia com a tempestade que lhe vai no íntimo.

- Meu Deus! murmurava Cirino, tudo quanto me rodeia está tão alegre e é tão belo! Com tanta leveza voam os pássaros: as flores são tão mimosas; os ribeirões tão claros... tudo convida ao descanso... só eu a padecer!

A longa série de descrições antecede os capítulos de clímax do romance, quando ocorreria o desenlace que com expectativa vinha sendo construído pela narrativa. As descrições se apresentam, pois, como os quadros paroxítonos em que a ação suspensa está prestes a se precipitar. Por outro lado, e de maneira ainda mais simples de se conceber, são esses quadros descritivos que conferem toda a singularidade ao romance, o qual, de outro modo, não estaria situado, podendo aludir a quaisquer outras narrativas alusivas a um amor irrealizável.

De acordo com Antonio Candido, a particularidade é a característica primordial da forma literária conhecida como romance, contrapondo-se ao caráter generalista e universalizante da epopeia. ${ }^{25}$ Candido exprime bem tal oposição ao afirmar que, apesar de se assemelhar à epopeia na ambição e amplitude, o romance não teria o intento de arrancar os homens da contingência para levá-los ao plano do milagre, mas sim encontrar o miraculoso nos ferrolhos do cotidiano.

Contrariamente aos gêneros narrativos anteriores, ocupados com o inaudito, o romance se prestaria a retratar todo tipo de experiência humana, talhando personagens como pessoas comuns, não correspondentes a figuras arquetípicas, e situados em um espaço e tempo determinados. Todos esses

${ }^{25}$ Ibidem, p. 430. 
elementos que em nossa época podem parecer naturais a narrativas literárias não eram requeridos pelas formas ficcionais anteriores, normalmente ambientadas em espaço e tempo vagos e genéricos. No caso do romance, tais particularidades conferiam verossimilhança à correspondência entre a obra literária e a realidade que ela imita, de modo que o emprego de descrições se mostrava imprescindível.

Alfredo Taunay assim o faz em Inocência. Delimita o espaço-tempo concreto: a região do rio Parnaíba, um lugarejo do leste sul-mato-grossense (na época de Taunay, sul de Mato Grosso, posto que o estado ainda não havia sido dividido), próximo ao oeste de Minas Gerais, delineia as personagens: há uma moça bonita e ingênua mantida reclusa pelo pai. São sertanejos, empregam o vocabulário das pessoas de pouca instrução, cujo convívio se restringe a um círculo limitado que compreende as pessoas dos sítios da cercania e do povoado mais próximo. São figuras comuns, reconhecíveis em muitas famílias dos rincões interioranos do Brasil oitocentista.

Operando um paralelo e nos apropriando das asserções relativas à literatura para pensar a pintura, poderíamos associar os fatos inauditos das grandes narrativas épicas à pintura histórica, que então passam a ser menos valorizados que os preenchimentos das cenas frugais e do aspecto do ambiente natural, que contornam os cenários da vida, como nas pinturas de paisagem de Hipólito Caron e seus companheiros de grupo.

Aos preenchimentos de Moretti não seria descabido justapor a observação de Rafael Cardoso, que identifica na pintura de Grimm e seus discípulos não a inovação da pintura ao ar livre, mas a novidade de um olhar que atenta para o entorno brasileiro com familiaridade:

Mais do que métodos supostamente revolucionários frequentemente destacados como contribuição de Grimm, ele evidencia um olhar plácido e familiar para a paisagem brasileira, e nisto sim reside uma grande novidade. Desde o final do século XVIII, a paisagem brasileira vinha sendo representada, ora de modo altamente preciso e analítico, ora de modo romantizado e exótico. Enquanto pintores ligados a expedições científicas 
dedicavam-se ao escrutínio de formas botânicas e vistas topográficas, outros viajantes não economizavam nas tintas cor-de-rosa e nos efeitos de luz penetrando em grutas e florestas escuras para ressaltar o caráter estranho e sublime da natureza dos trópicos. Em alguns casos extraordinários - Debret, Rugendas, Righini, Vinet, entre outros - às vezes conseguiam fazer ambas as coisas ao mesmo tempo. Antes de Grimm, porém, quase ninguém havia realizado a proeza maior com relação à paisagem brasileira: a de torná-la corriqueira. ${ }^{26}$

No período que permaneceu com Grimm, as pinturas de Caron lançam um olhar familiar também para alguns trechos de paisagens rurais. Ambientando tanto restingas quanto porções mais afastadas do mar, essas pinturas figuram cenários de um primitivismo suave; lugares em que a intervenção humana é entrevista - de modo semelhante à paisagem descrita em Inocência - apenas por uma estrada bem pisada ou uma porteira singela.

No Trecho de paisagem na restinga de Icaraí (Figura 2), a vegetação recorda a proximidade do mar, entretanto, não transfigura idílios. Nenhum tom exasperante que imprima deleite: apenas o dia firme e calmo, nuvens rarefeitas, estrada alva - talvez refletindo o sol - dando lugar à atividade corriqueira de um transeunte conduzindo uma cavalgadura.

Representando-a desse modo, é como se o olhar de Caron aplicado em descrever o trecho em repetidas sessões escolhesse imprimir nele o que o faria mais próximo e familiar: a imagem de alguém que passa, quando quem observa poderia também estar passando. Passaríamos contornando o ajuntamento de águas no primeiro plano, à esquerda; lançaríamos de relance os olhos sobre as cercas rudimentares, à extrema esquerda; e registraríamos, talvez, a presença de diferentes formatos de folhagens e aspectos das copas das árvores, ou apenas reteríamos a sensação fugidia da diversidade de verdes, da intensidade e do contraste da luz... Daquelas bananeiras sobressaindo junto à curva, quase no fundo à esquerda... Todo esse aspecto, que parece tão banal, no qual não há gravidade e que dificilmente atrairia contemplação reverente outrora, é fixado aqui minuciosamente.

\footnotetext{
${ }^{26}$ Rafael Cardoso, A Arte Brasileira em 25 Quadros (1790-1930), 2008, p. 83.
} 


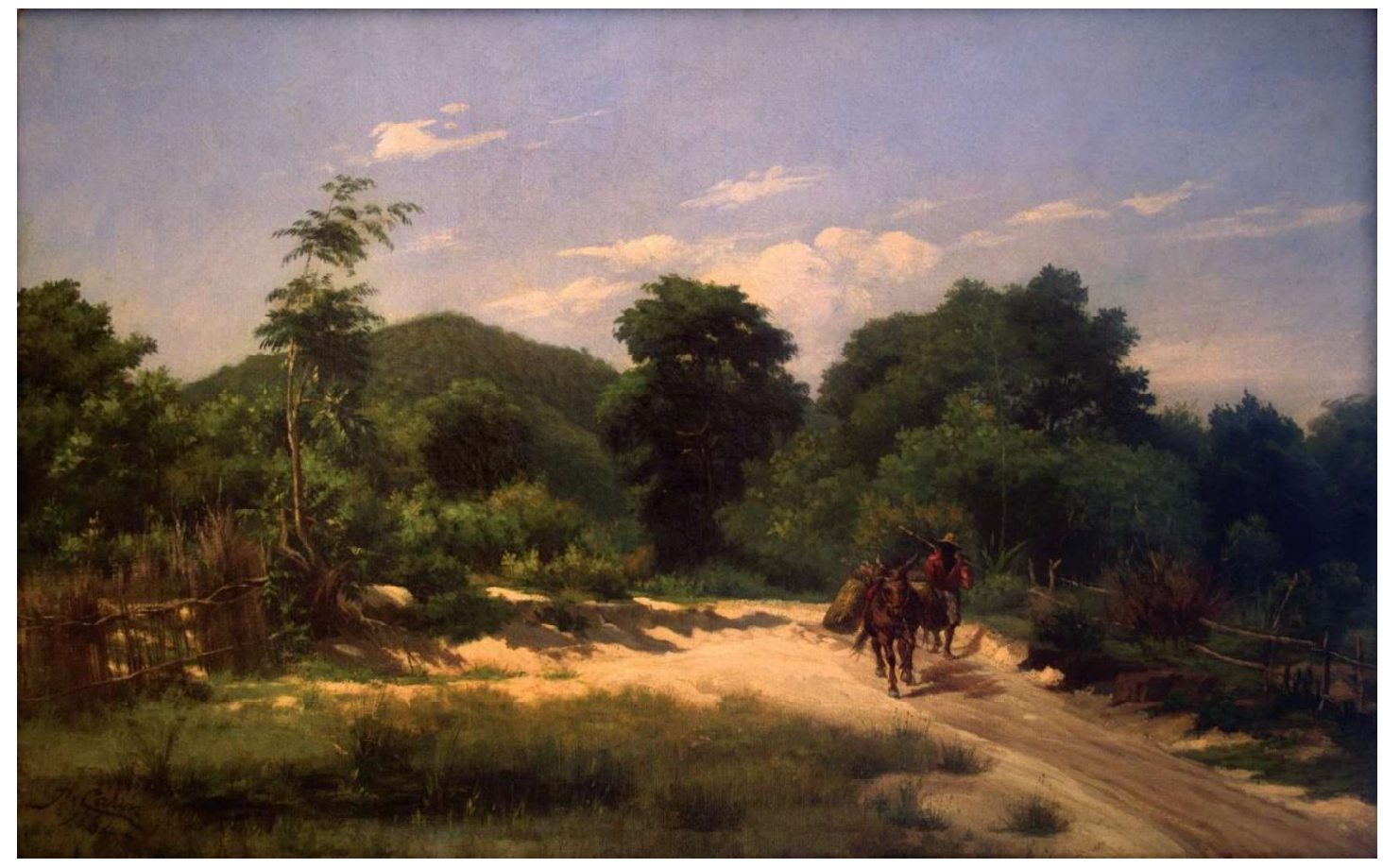

Figura 2

Hipólito Caron. Trecho de paisagem na restinga de Icaraí, 1884. Óleo sobre tela, 38,5 x $60 \mathrm{~cm}$.

Coleção Fadel, Rio de Janeiro, RJ.

O mesmo faz Alfredo Taunay em Inocência, assim como fazem outros romancistas, como Távora e Alencar, que pintam com palavras a paisagem vivida, vestem o verbo com pintura através das descrições compostas mediante a vivência dos lugares e a atenção do olhar. Em suas páginas há imagens e a experiência do visível. É aí então que o paradigma logocêntrico se inverte, e de submissa à poesia, a pintura passa a ser seu referencial, como a pintura deve ser o romance.

\section{Referências}

ARGAN, Giulio Carlo. Arte Moderna. São Paulo: Companhia das Letras, 2008. 
CANDIDO, Antonio. Formação da literatura brasileira: movimentos decisivos 1750-1880. 14. ed. Rio de Janeiro: Ouro sobre Azul, 2013.

CARDOSO, Rafael. A Arte Brasileira em 25 Quadros (1790-1930). Rio de Janeiro: Record, 2008.

ALENCAR, José de. Cartas sobre a Confederação dos Tamoyos. Rio de Janeiro: Empreza Typ. Nacional do Diario, 1856. Disponível em: http://www2.senado.leg.br/bdsf/handle/id/242822. Acesso em: 17 de Jul. 2019.

CAVALCANTI, Ana M. T. A pintura de paisagem ao ar livre e o anseio por modernidade no meio artístico carioca no final do século XIX. In: Cadernos da PósGraduação do Instituto de Artes/ Unicamp. Ano 6, v.6, n.1, 2002, p.28-34.

CHIARELLI, Tadeu. Gonzaga-Duque: a moldura e o quadro da arte brasileira. In DUQUE, Gonzaga. A arte brasileira. Campinas: Mercado de Letras, 1995.

DAZZI, Camila; VALLE, Arthur. 'As bellezas naturaes do nosso paiz': o lugar da paisagem na arte brasileira, do Império à República. Concinnitas (Rio de Janeiro. Impresso), v. 1, p. 120-133, 2009.

DUQUE, Gonzaga. A arte brasileira. Campinas: Mercado de Letras, 1995.

FILÓSTRATO. Amor e outras imagens. Trad. Rosângela Amato. São Paulo: Hedra, 2012.

LICHTENSTEIN, Jacqueline. A pintura: textos essenciais. Volume 7: O paralelo das artes. São Paulo: Ed. 34, 2005.

LICHTENSTEIN, Jacqueline. A pintura: textos essenciais. Volume 9: O desenho e a cor. São Paulo: Ed. 34, 2006.

MELLO, Celina M. M. de. A literatura francesa e a pintura - ensaios críticos. Rio de Janeiro: 7 Letras, 2004.

MORETTI. O século sério in A cultura do Romance. São Paulo: Cosac Naify, 2009. 
SCHWARCZ, Lilia M. O sol do Brasil: Nicolas-Antoine Taunay e as desventuras dos artistas franceses na corte de D. João. São Paulo: Companhia das Letras, 2008.

SCOTT, Walter. Marmion. Livros disponível em:

http://books.google.com.br/books/download/Marmion.pdf?

TAUNAY, Alfredo d'Escragnolle. Inocência. Livro disponível em:

http://www.dominiopublico.gov.br/pesquisa/DetalheObraForm.do?select_acti on $=\&$ co_obra $=2017$

\section{Referência para citação deste artigo}

DE BRITO, Ana. De Paisagens Escritas e Paisagens Pintadas: vínculos conceituais entre a pintura de Hipólito Caron e o romance Inocência de Alfredo Taunay. Revista PHILIA | Filosofia, Literatura \& Arte, Porto Alegre, volume 1, número 2, p. 42 - 67, outubro de 2019. 